Amelia Tryc* (iD https://orcid.org/0000-0002-5760-4943

Akademia Pedagogiki Specjalnej im. Marii Grzegorzewskiej w Warszawie e-mail:ameliatryc@gmail.com

\title{
Urlopy tacierzyńskie jako instytucjonalny dowód zmian w postrzeganiu roli ojca na przestrzeni lat
}

\begin{abstract}
Streszczenie: Charakterystyczne dla współczesności przemiany społeczne widoczne w obszarze rodziny wywołały także znaczące zmiany w postrzeganiu roli ojca. Tradycyjne ujęcie ojca jako autorytetu i głowy rodziny, zajętej „męskimi” sprawami, takimi jak organizowanie bytu i zarabianie pieniędzy, ustąpiły miejsca modelowi ojca-partnera matki we wszystkim, a więc także w opiece nad dzieckiem, w tym małym. Celem artykułu jest pokazanie transformacji ojcowskiego wizerunku w kontekście tego, w jaki sposób współcześni ojcowie biorą udział w opiece nad dziećmi kilkumiesięcznymi i młodszymi ze szczególnym uwzględnieniem urlopów tacierzyńskich jako instytucjonalnej zmiany w postrzeganiu wizerunku i roli ojca.
\end{abstract}

Słowa kluczowe: rodzina, stereotyp społeczny, ojcostwo, rola ojca, urlopy tacierzyńskie

* Amelia Tryc - studentka pedagogiki I roku studiów magisterskich na Akademii Pedagogiki Specjalnej im. Marii Grzegorzewskiej w Warszawie, autorka pracy licencjackiej Współczesne ojcostwo w percepcji mężczyzn przebywajacych na urlopie tacierzyńskim (2020). W kręgu jej głównych zainteresowań naukowych jest szeroko rozumiana problematyka związana z edukacją i wychowaniem dzieci młodszych, ze szczególnym uwzględnieniem relacji rodzinnych i modeli macierzyństwa oraz ojcostwa. Swoje zainteresowania naukowe uzupełnia doświadczeniem praktycznym gromadzonym w ramach pracy zawodowej - od kilku lat prowadzi zajęcia z dziećmi w wieku przedszkolnym i wczesnoszkolnym, które dają jej wiele satysfakcji i wzbogacają doświadczenie teoretyczne o aspekt praktyczny. 


\section{Wprowadzenie - przemiany w obszarze współczesnej rodziny jako punkt wyjścia do analizy zmieniającego się modelu ojcostwa}

Współczesny świat to rzeczywistość, która dynamicznie się zmienia, także w wymiarze społecznym, co łatwo można dostrzec na przykładzie rodziny - wspólnoty podstawowej i naturalnej. Jeszcze do niedawna w jej obszarze obowiązywał tradycyjny podział ról. Kobieta jako żona i matka zajmowała się domem i dziećmi, pełniąc funkcję opiekuńczą. Do niej należała opieka nad domowym ogniskiem, nierzadko związana $\mathrm{z}$ całkowitym poświęceniem się rodzinie, połączonym z rezygnacją z własnych marzeń i pragnień (np. z kariery zawodowej czy realizacji życiowych pasji). Tym samym opieka nad małym dzieckiem w sposób naturalny kojarzyła się z matką. To właśnie ona $\mathrm{z}$ reguły spędzała $\mathrm{z}$ nim pierwsze miesiące życia, karmiąc je, przewijając czy usypiając. W tym kontekście mężczyzna postrzegany był jako osoba, która spełniała wyłącznie rolę pomocniczą. Jego nadrzędnym zadaniem było pełnienie funkcji głowy rodziny. Należało do niego zapewnienie jej bytu materialnego, co nierzadko sprawiało, że całe dnie spędzał w pracy, zarabiając pieniądze. Dzieckiem zajmował się sporadycznie, w chwilach wolnych od obowiązków zawodowych. Zwykle kojarzony był z przyjemnościami, zabawami, nie zaś z codziennymi, często żmudnymi i monotonnymi czynnościami opiekuńczymi sprawowanymi wobec małego dziecka. Do pewnego czasu taki rodzinny podział ról miał charakter niejako naturalny i nie budził niczyich wątpliwości. Często uzasadniano go dodatkowo cechami przypisywanymi kobiecie (opiekuńczość, czułość, wrażliwość), których w domyśle mężczyzna-ojciec miał być pozbawiony. W ostatnich latach ten sztywny podział rodzinnych ról zaczął się jednak zmieniać, a społeczeństwo powoli przekonuje się do tego, że także ojciec może być doskonałym opiekunem dziecka nie tylko kilkuletniego, lecz także małego. Zmianie społecznego postrzegania ojca towarzyszą zmiany prawne - od roku 2010 chętni ojcowie mogą skorzystać z urlopu tacierzyńskiego przyznawanego w celu sprawowania opieki nad małym dzieckiem. Jak czują się ojcowie na takich urlopach? Czy nie mają wrażenia, że opieka nad małym dzieckiem jest czynnością niemęską? Czy radzą sobie z obowiązkami? Na te pytania autorka artykułu próbuje odpowiedzieć w niepublikowanej pracy licencjackiej, której zarys stanowi treść niniejszego opracowania.

\section{Tradycyjny model ojcostwa i jego związek ze stereotypami społecznymi}

W ujęciu tradycyjnym podstawowym zadaniem ojca była ochrona rodziny, do czego predysponowany był ze względu na swą siłę fizyczną, która pozwalała mu odsuwać zagrożenia od potencjalnie słabszych bliskich - kobiety i dzieci. Z kolei matki, które w tradycyjnym modelu rodziny pełniły role „ekspresyjno-integracyjne”, stereotypowo odpowiadały za zapewnianie dzieciom bezpieczeństwa i opieki, zaspokojenie ich emo- 
cjonalnych potrzeb oraz socjalizację. Zadania „instrumentalno-przystosowawcze” przypisywano ojcom i były one związane z uzyskaniem środków na utrzymanie rodziny ${ }^{1}$.

Stereotypowy, tradycyjny podział ról matki i ojca usprawiedliwiany był z jednej strony większym „zaangażowaniem” kobiet w proces prokreacji (kobieta „nosi” dziecko przez 9 miesięcy, to ona je rodzi i znosi związany z tym trud, karmi piersią, opiekuje się niemowlęciem, z którym przez początkowy okres jego życia praktycznie się nie rozstaje). Z drugiej natomiast strony tłumaczyło się go wyposażeniem kobiet i mężczyzn w inne cechy i predyspozycje („kobiece” i „męskie”). Według stereotypu ojcostwo angażuje mężczyznę tylko częściowo, podczas gdy macierzyństwo (także to łączone $z$ aktywnością pozadomową) „obowiązuje” kobietę przez całą dobę. W związku $\mathrm{z}$ aktywnością $\mathrm{w}$ sferze publicznej oraz przypisywanymi mężczyźnie cechami i kompetencjami uważany był on za rodzaj łącznika rodziny ze światem zewnętrznym i traktowany jako uosobienie pozarodzinnych wartości i ról, autorytet i wychowawca, duchowy przewodnik ${ }^{2}$.

W tradycyjnym modelu ojcostwa zakładano także, że istnieje różnica między bezwarunkową miłością macierzyńską, która jest naturalna, której nie trzeba zdobywać i na którą nie trzeba zasługiwać, a miłością ojcowską, która jest obwarowana warunkami i oczekiwaniami, jakie należy spełnić, by być kochanym przez ojca ${ }^{3}$. Zdaniem K. Pospiszyla „Ojciec, będąc pozbawiony tak silnego jak matka związku biologicznego z dzieckiem, nie posiada «danej z natury» umiejętności kochania dziecka tylko dlatego, że jest to jego dziecko"4. Według stereotypu ojciec jest rodzicem, względem którego dziecko ma być posłuszne. Stawia on przed nim wyraźne wymagania czy zasady postępowania. Wychowuje i przygotowuje dzieci do wejścia w pozarodzinne życie społeczne, nagradzając własną miłością bądź karząc jej odebraniem ${ }^{5}$.

Tradycyjny model ojcostwa w dużej mierze oparty był na stereotypach „naturalnego” podziału płci. W przypadku rodzicielstwa stereotypy płciowe uaktywniają się bardzo silnie, ponieważ przyjście na świat dziecka to moment, kiedy kobieta i mężczyzna łatwiej wchodzą w role przypisywane im ze względu na płeć, co w pewnym stopniu spowodowane jest społecznymi oczekiwaniami dotyczącymi zarówno roli matki, jak i roli ojca. Postrzeganie ról społecznych przez pryzmat stereotypów z jednej strony bardzo upraszcza rzeczywistość, z drugiej zaś jednak wprowadza poczucie ładu i niezaburzonego porządku ${ }^{6}$. Jak ujmuje to L. Kopciewicz: „[...] świat, który

1 K. Dzwonkowska-Godula, Ojcostwo jako instytucja i doświadczenie $w$ świetle wypowiedzi młodych wykształconych ojców, „Acta Universitatis Lodziensis. Folia Sociologica” 2011, nr 39, s. 114.

2 Tamże, s. 114.

3 E. Fromm, O sztuce miłości, PIW, Warszawa 1971, s. 52-56.

${ }^{4}$ K. Pospiszyl, Ojciec a wychowanie dziecka, Wydawnictwo Akademickie „Żak”, Warszawa 2007, s. 30 .

5 Tamże, s. 30.

${ }^{6}$ M. Bierca, Nowe wzory ojcostwa w Polsce, Wydawnictwo Borgis, Warszawa 2019, s. 34-36. 
został podzielony w tak czytelny sposób, jest światem zsektoryzowanym. [...] Tak czytelny obraz świata [...] powoduje, że wiemy, gdzie jest «nasze miejsce»"7.

Stereotypy odnoszące się do roli matki i ojca są bardzo silne, ponieważ zarówno macierzyństwo, jak i ojcostwo to instytucje. Jako takie poddawane są nieustannej kontroli społecznej i regulowane przez wyznaczane dla nich zasady działania, normy, nakazy, zakazy i powinności. Tym samym w ujęciu tradycyjnym bycie rodzicem, w tym ojcem, nie jest misją o indywidualnie wyznaczanych zasadach, a wejście w relacje partnerską z drugą dorosłą osobą i podjęcie decyzji o rodzicielstwie silnie wyostrza oczekiwania stawiane przez społeczeństwo tak kobiecie, jak i mężczyźnie. Podjęcie się roli rodzica oznacza zatem zetknięcie się z ogromną siłą stereotypowych wizji i oczekiwań, jakim powinien sprostać mąż i ojciec. Oczekiwania takie wyrażają świeckie instytucje społeczne w postaci dalszej rodziny, kręgu przyjaciół, znajomych, środowiska pracy ojca czy przedszkolnego i szkolnego środowiska dziecka. W kontekście polskim do oczekiwań tych dochodzi jeszcze wpływ Kościoła katolickiego jako instytucji, która bardzo silnie wzmacnia stereotypową wizję ról obojga partnerów ${ }^{8}$.

$\mathrm{W}$ ujęciu tradycyjnym partnerom będącym rodzicami przypisuje się zatem pewne cechy, z założenia mające ich różnicować i definiować jako jednostki z jednej strony odrębne płciowo, $z$ drugiej zaś uzupełniające się. Według stereotypowego założenia mężczyźni w relacji z kobietami powinni charakteryzować się umiłowaniem wolności i pragnieniem dominacji, natomiast kobiety cechuje uległość i zgoda na przedmiotowe traktowanie. W tak pomyślaną wizję rodziców wpisana jest idea nierównego układu, w którym to mężczyzna - mąż i ojciec - jest niejako istotą wyższą, natomiast kobieta może być traktowana z góry. Taki układ sił odpowiada za swoistą przyziemność codziennych kobiecych zadań i „bycie ponad” w przypadku mężczyzny. W konsekwencji to matkę charakteryzuje większa wnikliwość w świat dziecka i wykazywanie zainteresowania nawet najbardziej prozaicznymi sprawami związanymi z potomstwem, ojca natomiast cechuje dystans i oddalenie ${ }^{9}$. Z polaryzacją płci łączy się silna polaryzacja ról rodzicielskich. Matki kojarzone są z „miękkimi”, „kobiecymi” cechami, jak miłość, opiekuńczość czy ciepło (stereotyp „matczynej łagodności”), ojcowie natomiast z chłodem emocjonalnym, surowością, władczością (stereotyp „twardej ojcowskiej ręki”) ${ }^{10}$.

W ujęciu tradycyjnym mężczyzna pełni funkcję „żywiciela”, choć - jak zauważa K. Dzwonkowska-Godula - uproszczeniem byłoby stwierdzenie, że stereotypowo postrzegana rola ojca ogranicza się wyłącznie do utrzymywania rodziny i bycia jej głową. Ze względu na aktywność w sferze publicznej, a także z uwagi na przypisywa-

${ }^{7}$ L. Kopciewicz, Kobiecość, męskość i przemoc symboliczna. Polsko-francuskie studium porównawcze, Oficyna Wydawnicza „Impuls”, Kraków 2005, s. 194.

${ }^{8}$ M.M. Bierca, Nowe..., dz. cyt., s. 174.

9 Tamże, s. 176-177.

${ }^{10}$ K. Dzwonkowska-Godula, Tradycyjnie czy nowocześnie? Wzory macierzyństwa i ojcostwa $w$ Polsce, Wydawnictwo Uniwersytetu Łódzkiego, Łódź 2015, s. 57. 
ne mu cechy i kompetencje w modelu patriarchalnym mężczyzna staje się łącznikiem rodziny ze światem zewnętrznym, uosobieniem pozarodzinnych wartości i ról, autorytetem i wychowawcą, duchowym przewodnikiem. Do niego należą zatem przede wszystkim zadania wychowawcze, podczas gdy matce pozostają funkcje opiekuńcze. Choć to ona postrzegana jest jako osoba odpowiedzialna za socjalizację dziecka na pierwszym etapie jego życia, jej zadanie ogranicza się raczej do dbania o prawidłowy fizyczny i psychiczny rozwój dziecka, a także wyposażenie go w podstawową wiedzę na temat zasad zachowania. Ojciec przejmuje wychowanie dzieci dopiero wtedy, gdy stają się one bardziej samodzielne, co niejako łączy się z założeniem, że dziecko musi w pewnym sensie dorosnąć do tego, by stało się godne jego zainteresowania ${ }^{11}$. Jak podkreśla J. Mulliez: „[...] panował zwyczaj, że roztaczanie opieki nad maleństwem do siódmego roku życia należało do matki, a przed ojcem [dziecko] nie stawało, zanim nie osiągnęło wieku, w którym zasługuje się na poważanie"12.

W modelu tradycyjnym kobieta i mężczyzna mają pełnić odmienne funkcje rodzicielskie, a zatem bycie ojcem postrzegane jest jako zupełnie odmienne doświadczenie, łączące się z całkowicie innymi zadaniami. Zakłada się koncentrację mężczyzn na pracy zawodowej i nastawienie na zadbanie o sferę materialną funkcjonowania rodziny, co prowadzi do ograniczonej obecności ojca w domu i jego mniejszego zaangażowania w opiekę nad dzieckiem i wychowanie go ${ }^{13}$. Tym samym ojciec wypełnia $\mathrm{w}$ rodzinie zadania instrumentalno-przystosowawcze, związane ze zdobywaniem środków na utrzymanie rodziny, natomiast matka odpowiada za role ekspresyjno-integracyjne - do jej zadań należy zapewnienie dzieciom opieki i bezpieczeństwa, zaspokojenie ich potrzeb emocjonalnych, a także dbałość o ich socjalizację. Taki podział rodzicielskich ról z jednej strony uzasadniany jest większym „zaangażowaniem” kobiety w proces prokreacji (ciąża, poród, karmienie piersią), natomiast z drugiej rożnymi cechami i predyspozycjami tradycyjnie przypisywanymi kobietom i mężczyznom. Według tradycjonalistów taki rodzicielski podział ról z jednej strony ma charakter uniwersalny i naturalny, z drugiej natomiast jest konieczny, by rodzina mogła prawidłowo funkcjonować ${ }^{14}$.

\section{Nowoczesny model ojcostwa}

Nowoczesny wzorzec ojcostwa różni się od tradycyjnego brakiem stereotypów budujących jednoznaczną wizję rodzicielskiego świata. W tym ujęciu rodzicielstwo staje się wspólnym doświadczeniem, w którym partnerzy otwarcie wypełniają zada-

11 Tamże, s. 64 .

12 J. Mulliez, Desygnacja ojca, [w:] J. Delumeau, D. Roche (red.), Historia ojców i ojcostwa, Oficyna Wydawnicza Volumen, Warszawa 1995, s. 64.

13 M.M. Bierca, Nowe..., dz. cyt., s. 178.

14 K. Dzwonkowska-Godula, Tradycyjnie..., dz. cyt., s. 57-58. 
nia opiekuńcze i wychowawcze, starając się unikać wstępnego przypisania do jakiejkolwiek z ról. Zarówno bycie ojcem, jak i bycie matką przestaje oznaczać przejawianie określonego zestawu cech, co sprzyja tworzeniu relacji opartych na równości mężczyzny i kobiety. Tym samym punktem wyjścia nowoczesnego modelu ojcostwa jest założenie, że poza urodzeniem dziecka jako zadaniem naturalnie kobiecym każda inna aktywność rodzicielska w takim samym stopniu może być wykonywana przez każde z rodziców (we wzorcu tradycyjnym zakłada się natomiast, że mężczyzna pełni w rodzinie niejako rolę „mędrca”, natomiast kobieta - „piastunki”). Przy założeniu równości obu płci i obowiązków rodzicielskich przypisywanych kobiecie i mężczyźnie traci zasadność wartościowanie sfer aktywności matki i ojca jako prestiżowych, bo męskich, lub dających mniej powodów do dumy, bo kobiecych ${ }^{15}$. W tym ujęciu wszelkie zachowania rodzicielskie mogą zostać uznane za „czynność wyższą i honorującą albo za podstawowy obowiązek, niewymagający żadnych kwalifikacji i nieuprawniający do uznania zasług"16.

$\mathrm{W}$ modelu nowoczesnym zaangażowanie mężczyzny w bycie rodzicem uwidacznia się już na etapie ciąży i porodu, w których to momentach ojcowie chętnie towarzyszą partnerkom, podkreślając w ten sposób swoją aktywną obecność w życiu dziecka od samych jego początków. W nowoczesnym modelu ojcostwa bardzo istotne jest bowiem nie tylko to, by ojciec nawiązał z dzieckiem i wciąż umacniał niezwykle silną więź opartą na emocjach, uczuciach i wrażliwości, lecz także to, by była ona budowana jak najwcześniej, nawet jeszcze przed narodzinami ${ }^{17}$. Nowocześni ojcowie wspierają swoje partnerki w czasie ciąży, od początku ciesząc się z faktu nadchodzącego powiększenia rodziny. Towarzyszą im podczas badań okresowych i razem z nimi biorą udział w zajęciach szkoły rodzenia. Wczuwają się w stan kobiety i kierują na nią swą uwagę, wspierając ją. Także podczas porodu nie postrzegają go stereotypowo jako „kobiecej” sprawy. Od pierwszych chwil narodzin dziecka są razem z nim i z jego matką, co uważają za sytuację naturalną. Jak ujmuje to M.M. Bierca: „Posiadanie dziecka odbierane było przez nich jako wspólny projekt obojga partnerów, a zatem zostawienie partnerki samej byłoby zachowaniem nieadekwatnym"18.

Podczas dalszej opieki nad dzieckiem, nawet bardzo małym, ojcowie nowocześni uczestniczą w opiece nad nim i w jego wychowaniu. Współdziałają z partnerką i współdzielą z nią wiele czynności, uważając przy tym, że w ten sposób przekazują swoim dzieciom właściwe wzorce na przyszłość, czego dowodzi wypowiedź jednego z ojców badanych przez M.M. Biercę: „Nie może być tak, że matka w domu, ojciec pracuje, matka wewnątrz, ojciec na zewnątrz. Mamy już to równouprawnienie, to też

15 Tamże, s. 37, 178-179.

${ }^{16}$ J. Brach-Czaina, Kariatydy i kulturyści, [w:] J. Brach-Czaina (red.), Od kobiety do mężczyzny i z powrotem. Rozważania o płci w kulturze, Wydawnictwo Trans Humana, Białystok 1997, s. 252.

17 M. Sikorska, Nowa matka, nowy ojciec, nowe dziecko, Wydawnictwa Akademickie i Profesjonalne, Warszawa 2009, s. 193.

18 M.M. Bierca, Nowe..., dz. cyt., s. 196-203. 
musimy to tym dzieciom zaszczepiać. Ale jeśli już mamy takie wzorce, to trzeba to przekazać. I uważam, że ojciec daje tyle samo, co matka [...]"19. Nowocześni ojcowie nie obawiają się kąpać nawet bardzo małych dzieci, a także zmieniają pieluchy. Wspomagają swoje partnerki w karmieniu, podając i odkładając dziecko do łóżeczka czy ułatwiając mu odbijanie po jedzeniu. Nocami wstają do płaczących dzieci. Kiedy matka karmi, ojcowie wykonują inne czynności domowe czy przygotowują posiłek dla pary. Wymieniają się w czuwaniu przy łóżeczku dziecka, uważając usypianie i uspokajanie malucha za czynność, która może być wykonywana przez każdego z rodziców. Nie mają oporów przed tym, by spacerować z dzieckiem lub wychodzić z nim na plac zabaw. Odprowadzają czy odwożą dziecko do przedszkola, a także razem z nim uczestniczą w pozaprzedszkolnych zajęciach dodatkowych (np. warsztatach z rodzicami). Kiedy istnieje taka potrzeba, prowadzą dziecko do lekarza. Nie szkoda im wykorzystywać urlopu na opiekę nad chorym dzieckiem. Wykonują w domu stereotypowo „kobiece” czynności, jak sprzątanie czy gotowanie. Co niezwykle istotne, swej aktywności w tym względzie nie postrzegają jako „pomagania”, typowego dla porządku patriarchalnego, lecz raczej mówią o wspólnocie i naturalnym współdzieleniu obowiązków ${ }^{20}$.

\section{Podsumowanie różnic pomiędzy tradycyjnym a nowoczesnym modelem ojcostwa}

Wymienione powyżej zajęcia i działania „nowego” ojca dowodzą, że wraz z upadkiem tradycyjnego patriarchalnego modelu rodziny, w której kobieta była podporządkowana mężczyźnie, nastąpiło przejście od społecznego postrzegania funkcji mężczyzny jako „żywiciela” do roli „opiekuna”, aktywnie uczestniczącego w wychowaniu rodzinnym. Zmiany kulturowe doprowadziły do tego, że obok modelu ojcostwa tradycyjnego pojawił się nowoczesny wzorzec ojcostwa jako alternatywa wobec tamtego. W modelu tradycyjnym dość mocno zarysowany jest stereotypowy podział rodzinnych ról. Ojciec pełni tu funkcję głowy rodziny, a pozostali członkowie są w mniejszym lub większym stopniu podporządkowani jego władzy. Rola ojca polega przede wszystkim na zapewnieniu całej rodzinie bezpieczeństwa, żywności, a także innych podstaw bytu materialnego. Jako żywiciel rodziny ojciec ponosi odpowiedzialność za dzieci i ich matkę. Pełni funkcję wychowawcy i autorytetu, którego zadanie polega na wyznaczeniu dziecku właściwego kierunku postępowania oraz życiowej drogi. Ojciec tradycyjny stanowi wzór męskich cech osobowości, jest odzwierciedleniem siły fizycznej i odwagi. W razie potrzeby (np. nieposłuszeństwa wobec niego) może okazywać surowość i karcić swe dzieci, a nawet je karać. Z jednej strony troszczy się on zatem o rodzinę, z drugiej zaś jest wszechwiedzący, stawia dziecku ogromne

\footnotetext{
19 Tamże, s. 209.

20 Tamże, s. 208-217.
} 
wymagania i nie ukrywa swego rozczarowania, gdy spotka się z jakimkolwiek nieposłuszeństwem czy sprzeciwem ${ }^{21}$. Najważniejsze różnice pomiędzy ojcostwem tradycyjnym i nowoczesnym ukazuje tabela 1 .

Tabela 1. Porównanie tradycyjnego i nowoczesnego modelu ojcostwa

\begin{tabular}{|l|l|}
\hline \multicolumn{1}{|c|}{ Tradycyjny } & \multicolumn{1}{c|}{ Nowoczesny } \\
\hline silne podstawy i odniesienia religijne & brak silnej orientacji na religię \\
\hline stereotypowy podział ról w życiu rodzinnym & związek o charakterze partnerskim \\
\hline $\begin{array}{l}\text { zaangażowany w codzienną opiekę i wychowanie } \\
\text { dziecka w stopniu znacznie mniejszym niż matka }\end{array}$ & $\begin{array}{l}\text { obowiązki rodzicielskie w sposób partnerski } \\
\text { podzielone pomiędzy matkę i ojca }\end{array}$ \\
\hline $\begin{array}{l}\text { surowo ocenia dzieci, zarówno one, jak i żona } \\
\text { podporządkowane są jego władzy }\end{array}$ & $\begin{array}{l}\text { ciepłe, serdeczne relacje pomiędzy ojcem } \\
\text { a dzieckiem i matką }\end{array}$ \\
\hline $\begin{array}{l}\text { demonstruje swą dominującą pozycję w rodzinie } \\
\text { w stosunku do dzieci i żony }\end{array}$ & jest partnerem i przyjacielem swoich dzieci i żony \\
\hline ma problem z okazywaniem uczuć & nie ma problemu z okazywaniem uczuć \\
\hline $\begin{array}{l}\text { często nieobecny w życiu dzieci, zarówno fizycznie, } \\
\text { jak i duchowo }\end{array}$ & obecny w życiu dziecka w każdym momencie \\
\hline $\begin{array}{l}\text { uważa, że wie, co dla jego dzieci jest najlepsze - jest } \\
\text { niezadowolony, gdy wybierają one swą drogę życiową } \\
\text { niezgodną z jego wyobrażeniami }\end{array}$ & $\begin{array}{l}\text { pomaga w dokonywanych przez dziecko wyborach } \\
\text { życiowych, wspiera je w jego decyzjach }\end{array}$ \\
\hline
\end{tabular}

Źródło: opracowanie własne na podstawie T. Sosnowski, Ojcostwo w perspektywie pokoleniowej. Studium socjopedagogiczne, Wydawnictwo Naukowe „Scholar", Warszawa 2018, s. 141.

\section{Urlopy tacierzyńskie jako prawno-społeczny dowód przekształceń w modelu ojcostwa}

Opisane powyżej przemiany w postrzeganiu modelu ojcostwa znalazły swe odzwierciedlenie na poziomie instytucjonalnym - w postaci tzw. urlopów tacierzyńskich przeznaczonych dla ojców, którzy chcieliby wziąć dni wolne, by w tym czasie zająć się dzieckiem. Temat takich urlopów od połowy pierwszej dekady XXI wieku był coraz częściej obecny w mediach i zaczął też pojawiać się w kulturze masowej. W roku 2010, w wyniku starań A. Chłoń-Domińczak, podsekretarz stanu w Ministerstwie Pracy i Polityki Społecznej, w Polsce został wprowadzony urlop ojcowski mający wymiar jednego tygodnia. Od stycznia 2012 roku urlop ten wydłużono do 2 tygodni. W międzyczasie Ministerstwo Pracy i Polityki Społecznej uruchomiło portal urlopojcowski. info, by podnosić świadomość dostępności rozwiązań prawnych, zachęcać mężczyzn do korzystania $\mathrm{z}$ tego rodzaju możliwości i promować je wśród pracodawców ${ }^{22}$. Za pierwszym rozwiązaniem poszły kolejne. Dnia 17 czerwca 2013 roku weszła w życie

${ }^{21}$ T. Sosnowski, Ojcostwo w perspektywie pokoleniowej. Studium socjopedagogiczne, Wydawnictwo Naukowe „Scholar”, Warszawa 2018, s. 138-140.

${ }^{22}$ Tamże, s. 79. 
nowelizacja ustawy o przyznawaniu urlopów, określanych dotąd mianem rodzicielskich. Dokonano wtedy zmiany przepisów dotyczących urlopu, który przysługuje obojgu rodzicom - odtąd podstawowy urlop macierzyński wynosi 20 tygodni (z czego 14 pierwszych tygodni należy się tylko matce). Kolejną opcjonalną formą jest urlop rodzicielski, który trwa 32 tygodnie i może być dzielony pomiędzy oboje rodziców ${ }^{23}$.

Warto podkreślić, że potoczna, zwyczajowa nazwa urlopu tacierzyńskiego obejmuje tak naprawdę trzy urlopy:

1. Część urlopu macierzyńskiego, którą matka dziecka może przekazać jego ojcu (rodzice mogą skorzystać także z tzw. dodatkowego urlopu macierzyńskiego, który trwa 6 tygodni (do wykorzystania przed porodem lub po właściwym urlopie macierzyńskim, również przez ojca dziecka).

2. Urlop ojcowski, do którego ojciec zatrudniony na umowę o pracę ma prawo w wymiarze 2 tygodni, a na jego wykorzystanie ma 2 lata (urlop ten ojciec może wykorzystać w całości lub podzielić na dwie części, jednak żadna z nich nie może być krótsza niż tydzień).

3. Urlop rodzicielski, którego długość wynosi 32 tygodnie ${ }^{24}$.

W pierwszym przypadku wymiar urlopu ojcowskiego zależy od decyzji matki dziecka, która może zdecydować się na oddanie ojcu jego części. W Polsce urlop macierzyński trwa od 20 do 31 tygodni. Matka musi skorzystać z pierwszych 14 tygodni urlopu, by następnie pozostałą część przekazać mężczyźnie. W tym przypadku długość urlopu tacierzyńskiego może wynieść do 6 tygodni przy urodzeniu się jednego dziecka (ciąża mnoga odpowiednio zwiększa długość urlopu dla obojga rodziców, a zatem także dla ojca ${ }^{25}$ ).

W przypadku ostatnim trzecią formą urlopu, którą ojciec może wykorzystać do opieki nad dzieckiem i który także bywa nazywany tacierzyńskim, jest urlop rodzicielski - jeśli po zakończeniu urlopu macierzyńskiego rodzice dalej chcą osobiście zajmować się dzieckiem, zarówno matka, jak i ojciec mogą skorzystać z urlopu rodzicielskiego, którego długość wynosi 32 tygodnie. Urlop ten może być jednocześnie wykorzystywany przez oboje rodziców. Udziela się go jednorazowo lub maksymalnie

${ }^{23}$ M. Bierca, Urlopy „tacierzyńskie” w Polsce - silny trend czy chwilowa moda? Rozważania w kontekście przemian ról w rodzinie, „Studia Socjologiczne” 2014, nr 4, s. 46.

${ }^{24}$ Urlop ojcowski 2019: ile trwa, komu przysługuje, kto płaci, dokumenty, https://www.edziecko. pl/rodzice/7,79318,21330922,urlop-ojcowski-2019-ile-trwa-komu-przysluguje-kto-placi.html [dostęp: 8.01.2020].

${ }^{25}$ Połączenie 20 i 32 tygodni razem daje 52 tygodnie, podczas których rodzice mogą zajmować się swoimi dziećmi. Jeśli na świat przyjdą wieloraczki, długość urlopów odpowiednio wynosi od 31 do 37 tygodni urlopu macierzyńskiego oraz do 34 tygodni urlopu rodzicielskiego. Razem może to być od 65 do nawet 71 tygodni, zależnie od liczby dzieci. Zob. P. Rojek-Socha, Urlop rodzicielski? Ojcowie coraz chętniej, https://www.prawo.pl/kadry/urlop-rodzicielski-ojcowie-coraz-chetniej-korzystaja-zus,376425.html [dostęp: 8.01.2020]; Urlop tacierzyński: zasady, komu przysługuje, ile trwa i jak złożyć wniosek?, https://dziennikzachodni.pl/urlop-tacierzynski-zasady-komu-przysluguje-ile -trwa-i-jak-zlozyc-wniosek/ar/13130784 [dostęp: 8.01.2020]. 
w czterech częściach, nie później niż do zakończenia roku kalendarzowego, w którym dziecko kończy 6. rok życia ${ }^{26}$.

Skomplikowane regulacje prawne w wymiarze urlopów przysługujących ojcom pragnącym opiekować się swoimi małymi dziećmi przekładają się na niepełny stan wiedzy społeczeństwa na ich temat. Pomimo nie do końca wyczerpującej wiedzy badanych na temat urlopów ojcowskich są one jednak przez respondentów odbierane bardzo pozytywnie. Według 69\% mężczyzn jest to dobry sposób na zaangażowanie ojców w opiekę nad dziećmi, a dla 65\% urlopy ojcowskie mają znaczenie w kontekście budowania relacji partnerskich w rodzinie. Ponad połowa badanych mężczyzn (53\%) nie zgadza się z opinią, że urlopy ojcowskie prowadzą do zaburzenia naturalnego podziału rodzinnych ról ${ }^{27}$.

Na temat korzystania przez ojców z urlopów tacierzyńskich istnieje niewiele statystyk. Najwięcej oferuje ZUS, z którego danych wynika, że w roku 2010 z urlopu ojcowskiego skorzystało wyłącznie 30 tys. pracowników z około 500 tys. uprawnionych, czyli około 2,5 tys. ojców miesięcznie. W roku 2011 było to jednak już 17 tys. ojców w okresie od stycznia do kwietnia ${ }^{28}$. Według najnowszych danych coraz większa liczba ojców wykazuje zainteresowanie urlopami przeznaczonymi na opiekę nad dziećmi - z danych GUS wynika, że tylko w styczniu 2019 roku z urlopów takich skorzystało 18,1 tys. mężczyzn, czyli więcej niż w styczniu 2018 roku, kiedy to na urlop rodzicielski udało się 17,3 tys. ojców ${ }^{29}$. W okresie od stycznia do września roku 2019 z 2-tygodniowego urlopu ojcowskiego skorzystało 150,3 tys. mężczyzn, natomiast 9,4 tys. mężczyzn przejęło część urlopu macierzyńskiego od swoich partnerek. Z 32-tygodniowego urlopu rodzicielskiego skorzystało 3,4 tys. mężczyzn ${ }^{30}$.

Pomimo rosnących statystyk zwyczaj brania przez ojców urlopów przeznaczonych na opiekę nad małymi dziećmi wciąż nie jest powszechny, co może wynikać $z$ różnych przyczyn. K. Suwada, która w drugiej dekadzie XXI wieku badała to zjawisko, podkreśla, że wiele kobiet, z którymi prowadziła wywiady, uważało, że urlop rodzicielski jest ich przywilejem i nie chciały odstępować jego części ojcu dziecka. Wielu ojców nie wiedziało też, że mają prawo do skorzystania z takiego urlopu równo z matką. Badania K. Suwady nie potwierdziły obiegowej opinii, że podstawową motywacją ojców idących na urlop są względy finansowe w sytuacji, gdy to kobieta więcej zarabia. Wśród analizowanych przez nią przypadków wielu mężczyzn, któ-

${ }^{26}$ T. Wróblewski, Urlop tacierzyński 2019, ojcowski 2019, rodzicielski 2019. Kto płaci, jak napisać wniosek, ile dni? Narodziny dziecka, przywileje dla ojca, https://nto.pl/urlop-tacierzynski2019-ojcowski-2019-rodzicielski-2019-kto-placi-jak-napisac-wniosek-ile-dni-narodziny-dziecka -przywilejela/ar/13644605 [dostęp: 8.01.2020].

${ }^{27}$ M. Bierca, Urlopy..., dz. cyt., s. 46-47, 52-54.

${ }^{28}$ M. Bierca, Tacierzyństwo w sieci - analiza nowego trendu i jego socjologiczne implikacje, „InterAlia: Pismo poświęcone studiom queer" 2013, nr 8, s. 80.

${ }^{29}$ P. Rojek-Socha, dz. cyt.

${ }^{30}$ Ojcowie zostaja $z$ dziećmi. Coraz częściej korzystaja z urlopów, https://www.forbes.pl/wiadomosci/urlop-rodzicielski-ojcowie-coraz-czesciej-zostaja-z-dziecmi/crks006 [dostęp: 8.01.2020]. 
rzy zdecydowali się na urlop, zarabiało tyle samo, co ich partnerki, lub nawet trochę więcej. Decydowali się oni jednak na urlop przede wszystkim dlatego, że narodziny dziecka postrzegali jako najważniejsze wydarzenie w życiu, a rodzicielstwo traktowali jako obowiązek i odpowiedzialność. Byli to z reguły mężczyźni z dużych miast z klasy średniej, mający wyższe wykształcenie i wysoką świadomość nierówności pomiędzy kobietami i mężczyznami ${ }^{31}$.

Przedstawione dane i spostrzeżenia socjologów prowadzą do wniosku, że na urlop ojcowski z jednej strony wciąż decyduje się stosunkowo niewielki odsetek mężczyzn, co spowodowane jest przede wszystkim utrwalonym stereotypem dotyczącym podziału rodzicielskich ról, a także powszechnym przekonaniem, że w kwestii opieki nad dzieckiem i jego wychowania to matka posiada wyższe kompetencje i umiejętności opiekuńczo-wychowawcze. Z drugiej jednak strony ci ojcowie, którzy wzięli taki urlop, widzą korzyści, wyrażające się choćby w faworyzowaniu ich w ośrodkach służby zdrowia czy placówkach usługowych. Często postrzega się ich wprawdzie jako grupę wymagającą pomocy i wsparcia, są jednak akceptowani społecznie i coraz częściej doceniani i podziwiani za to, że chcą realizować się w nowej roli. Satysfakcję i dumę w wymiarze osobistym przynosi im także świadomość, że opiekując się swoim małym dzieckiem, umacniają z nim więź. Przebywając na urlopie i opiekując się dzieckiem, niejako odkrywają oni nowe własne możliwości, uczucia i emocje, a sprawdzenie się w nowej sytuacji zmniejsza u nich poczucie stresu i poprawia samopoczucie. Walory urlopów ojcowskich dostrzegane są także przez same kobiety, ponieważ patrzą one wtedy na mężczyzn jak na odpowiedzialnych opiekunów ${ }^{32}$.

\section{Podsumowanie}

Współczesny ojciec nie jest już patriarchą, głową rodziny, a jego działania nie ograniczają się wyłącznie do zarabiania pieniędzy. Ojcowie stają się partnerami w pełni zaangażowanymi nie tylko w życie i obowiązki rodzinne, ale także w opiekę i wychowanie dzieci, którym poświęcają każdą wolną chwilę. Są otwarci na dialog z partnerką życiową oraz potomstwem, co wpływa korzystnie zarówno na życie rodzinne, jak i na budowanie relacji z dziećmi. Urlopy tacierzyńskie stanowią kolejny krok w przełamaniu stereotypu mówiącego, że opieka nad dzieckiem należy tylko do matki.

${ }^{31}$ A. Cichocka-Bielicka, Urlopy tacierzyńskie kosztem macierzyńskich? W polskich rodzinach bez zmian, nadal to matki zostaja na urlopie z potomstwem, https://nowosci.com.pl/urlopy-tacierzynskie-kosztem-macierzynskich-w-polskich-rodzinach-bez-zmian-nadal-to-matki-zostaja-na -urlopie-z-potomstwem/ar/c6-14376019 [dostęp: 8.01.2020].

32 A. Dudak, Obraz ojca w zmieniającej się rzeczywistości społecznej, „Pedagogika Społeczna” 2017, nr 2, s. 124-125. 


\section{Bibliografia}

Bierca M., Nowe wzory ojcostwa w Polsce, Wydawnictwo Borgis, Warszawa 2019.

Bierca M., Tacierzyństwo w sieci - analiza nowego trendu i jego socjologiczne implikacje, „InterAlia: Pismo poświęcone studiom queer” 2013, nr 8.

Bierca M., Urlopy „tacierzyńskie” w Polsce - silny trend czy chwilowa moda? Rozważania $w$ kontekście przemian ról w rodzinie, „Studia Socjologiczne” 2014, nr 4.

Brach-Czaina J., Kariatydy i kulturyści, [w:] J. Brach-Czaina (red.), Od kobiety do mężczyzny i z powrotem. Rozważania o płci w kulturze, Wydawnictwo Trans $\mathrm{Hu}-$ mana, Białystok 1997.

Cichocka-Bielicka A., Urlopy tacierzyńskie kosztem macierzyńskich? W polskich rodzinach bez zmian, nadal to matki zostaja na urlopie z potomstwem, https:// nowosci.com.pl/urlopy-tacierzynskie-kosztem-macierzynskich-w-polskich -rodzinach-bez-zmian-nadal-to-matki-zostaja-na-urlopie-z-potomstwem/ ar/c6-14376019 [dostęp: 8.01.2020].

Dudak A., Obraz ojca w zmieniającej się rzeczywistości społecznej, „Pedagogika Społeczna” 2017, nr 2.

Dzwonkowska-Godula K., Ojcostwo jako instytucja i doświadczenie w świetle wypowiedzi młodych wykształconych ojców, „Acta Universitatis Lodziensis. Folia Sociologica" 2011, nr 39.

Dzwonkowska-Godula K., Tradycyjnie czy nowocześnie? Wzory macierzyństwa i ojcostwa w Polsce, Wydawnictwo Uniwersytetu Łódzkiego, Łódź 2015.

Fromm E., O sztuce miłości, PIW, Warszawa 1971.

Kopciewicz L., Kobiecość, męskość i przemoc symboliczna. Polsko-francuskie studium porównawcze, Oficyna Wydawnicza „Impuls”, Kraków 2005.

Mulliez J., Desygnacja ojca, [w:] J. Delumeau, D. Roche (red.), Historia ojców i ojcostwa, Oficyna Wydawnicza Volumen, Warszawa 1995.

Ojcowie zostaja z dziećmi. Coraz częściej korzystaja z urlopów, https://www.forbes. pl/wiadomosci/urlop-rodzicielski-ojcowie-coraz-czesciej-zostaja-z-dziecmi/ crks006 [dostęp: 8.01.2020].

Pospiszyl K., Ojciec a wychowanie dziecka, Wydawnictwo Akademickie „Żak”, Warszawa 2007.

Rojek-Socha P., Urlop rodzicielski? Ojcowie coraz chętniej, https://www.prawo.pl/kadry/urlop-rodzicielski-ojcowie-coraz-chetniej-korzystaja-zus, 376425.html [dostęp: 8.01.2020].

Sikorska M., Nowa matka, nowy ojciec, nowe dziecko, Wydawnictwa Akademickie i Profesjonalne, Warszawa 2009.

Sosnowski T., Ojcostwo w perspektywie pokoleniowej. Studium socjopedagogiczne, Wydawnictwo Naukowe „Scholar”, Warszawa 2018.

Urlop ojcowski 2019: ile trwa, komu przysługuje, kto płaci, dokumenty, https://www. edziecko.pl/rodzice/7,79318,21330922,urlop-ojcowski-2019-ile-trwa-komu -przysluguje-kto-placi.html [dostęp: 8.01.2020]. 
Urlop tacierzyński: zasady, komu przysługuje, ile trwa i jak złożyć wniosek?, https:// dziennikzachodni.pl/urlop-tacierzynski-zasady-komu-przysluguje-ile-trwa -i-jak-zlozyc-wniosek/ar/13130784 [dostęp: 8.01.2020].

Wróblewski T., Urlop tacierzyński 2019, ojcowski 2019, rodzicielski 2019. Kto płaci, jak napisać wniosek, ile dni? Narodziny dziecka, przywileje dla ojca, https:// nto.pl/urlop-tacierzynski-2019-ojcowski-2019-rodzicielski-2019-kto-placijak-napisac-wniosek-ile-dni-narodziny-dziecka-przywilejela/ar/13644605 [dostęp: 8.01.2020].

\title{
Paternity leaves as an institutional proof of changes in the perception of the father's role over the years
}

Abstract: The social changes characteristic of the present days, visible in the area of the family, have also caused significant changes in the perception of the father's role. The traditional perception of him as the authority and head of the family, busy with "male" matters, like organizing one's existence and earning money, gave way to the father-mother's partner model in everything, including caring for the child as well as the little one. The aim of the article is to show the transformation of the paternal image in the context of how contemporary fathers take part in caring for children several months old and younger, with particular emphasis on paternity leave as an institutional change in the perception of the image and role of the father.

Keywords: family, social stereotype, fatherhood, the role of the father, paternity leave

\begin{abstract}
About the Author
Amelia Tryc - a student of pedagogy of the first year of M.A. studies at the Academy of Special Education Maria Grzegorewska in Warsaw, the author of a B.A. thesis on Contemporary fatherhood in the perception of men on paternity leave (2020). Her main research interests include issues related to the education and upbringing of younger children, with particular emphasis on family relationships and models of motherhood and fatherhood. She supplements her scientific interests with practical experience gathered during her professional work - for several years she has been conducting classes with preschool and early school children, which provide her with a lot of satisfaction and enrich theoretical experience with a practical aspect.
\end{abstract}

